\title{
Recent Publications
}

BOOK REVIEWS

Leighton, Phillip D., and David C. Weber. Planning Academic and Research Library Buildings. Chicago: American Library Assn., 1986. 2d ed. 630p. $\$ 60$ (ISBN 0-8389-3320-3). LC 85-11207.

Anyone who has undertaken the planning of an academic research library during the past twenty years would probably not have considered the task without a copy of Keyes Metcalf's Planning Academic and Research Library Buildings at hand. The widely accepted reputation and authority of this work in the field of library planning made Leighton and Weber's challenge in undertaking the writing of a second edition formidable. Leighton and Weber have organized this edition around the broad outlines of the planning process. Material on specific planning topics, to which Metcalf devoted the first two-thirds of his work, is folded into the planning process, with individual topics appearing whenever they are relevant to a particular planning stage. For the reader who is new to library planning, the broad range of specific planning topics that pop up at almost every step in the process may seem confusing and somewhat frustrating. On the other hand, it is this willingness to let the unavoidable complexity of library planning be visible that is one of the authors' most significant contributions.

Those familiar with Metcalf will probably still miss the convenience of the topical discussions about book stacks, traffic patterns, reader accommodations, etc. The appendixes still offer a wealth of specific information organized topically. In addition, the thorough indexing greatly reduces the possibility of missing important pieces of topical information that appear in the broader planning discussions. This edition also includes a wealth of useful and informative illustrations.

Planning an academic research library is intrinsically a complex and tangled matter. Leighton and Weber have done a commendable job of discussing the planning process from start to finish, allowing the complexity to show while bringing an impressive degree of order and clarity to their presentation. Anyone setting out on a first effort at planning the new construction or the renovation of an academic library building will be well served by this book. Those of us who have spent a few years engaged in library planning and are confident that we "know Metcalf" also owe it to ourselves to give this book a thorough reading.

The book will quickly establish its place in the working collections of library planners. Though this project may have begun as an effort to update Metcalf, what has resulted is not only a major revision but also a significant addition to the literature of academic library planning. The degree to which this work advances the literature of library planning is understated by calling it a second edition. It is fully capable of standing on its own merits and should, in time, be known with equal respect as "Leighton and Weber."-Donald G. Kelsey, University of Minnesota Libraries, Minneapolis.

Research Libraries: The Past 25 Years, the Next 25 Years. Papers for a Festschrift Honoring L. A. Anderson. Ed. by Taylor E. Hubbard. Boulder, Colo.: Colorado Associated Univ. Pr., 1986. \$25 (ISBN 087081-163-0). LC 86-2327. 
Generally, festschrifts in librarianship are interesting conglomorations of papers by acquaintances of the person being honored, gathered over time by an editor, most often useful tutorials in the authors' fields, and not altogether intellectually stimulating. One can usually count on them for state-of-the-art presentations in a broad field.

This one is different. It is actually the proceedings of a festschrift ceremony held at Colorado State University, where Anderson was director of libraries from 1957 until his recent retirement. The speakers were few: those well associated with research librarianship, as well as colleagues in various relationships with Anderson. The ceremony was relatively brief, hence the proceedings can be read quite quickly. And there was a theme, so there is coherence among the papers, some of which are expository, some of which are analytical. All present the personal views of the authors.

Shirley Echleman's brief opening paper sets forth a statement of some rather broad questions that face the research library community as it moves from the traditional to the new information age. A review of the proceedings of the Association of Research Libraries for the past few years will extend her analysis but will leave the basic questions open for development. Forrest Carhart, retired executive director of the New York Metropolitan Reference and Research Library Agency, now a resident of Colorado, reports in some detail how the New York State Three-Rs program developed into a successful array of cooperative activities among New York City's hundreds of large and small research libraries. The presentation is suggestive, but not analytical.

The remainder of the volume consists of five papers from people now or until recently associated directly with the operations of research libraries and contains the few brief, but cogent, analyses and commentaries. Ralph Ellsworth clearly makes the case for the modular library building as the only way to accommodate the kinds of changes that research libraries might have to make to match demands of the new information age. Richard Dougherty faces the inevitability of the substitution of electronic and other forms of access to library collections and their contents for open-shelf browsing and advises us to begin now to help scholars to adapt. David Stam quickly analyzes the collection development and preservation problems of research libraries and describes in general the workings of the Research Libraries Group's cooperative programs in these areas. His apt view that access to information about collection goals, collecting strengths, and items selected for preservation is one of the keys to the potential success of such cooperation adds strength to the arguments for new methods of access of others in this volume.

Richard McCoy's personal views of research library problems in providing access to information in and about library collections are based on his years as president of the Research Libraries Group. He makes a most clear analysis of the similarities and differences among various network activities (e.g., OCLC and RLG) and argues well for interaction, integration, and reduction of conflict among them on behalf of the scholarly user. Finally, G. Edward Evans of the Harvard University Library staff and formerly a faculty member at both UCLA and the University of Denver, speculates on the nature of the research library in the year 2010, giving us three scenarios of potential development and analyzing information access and management problems in each case.

All in all, this is a most enjoyable, though brief volume. Most of those in management positions of research libraries have already thought about one or another of the issues, and much has been written about them. It is useful, nevertheless, to pause briefly to read these words of a few of our major agents for change in research librarianship.-Russell Shank, University Libraries, University of California, Los Angeles.

Schauer, Bruce P. The Economics of Managing Library Service. Chicago: American Library Assn., 1986. 278p. $\$ 49$ (ISBN 08389-0453-X). LC 86-14186.

Detailed, academic approaches to library budgets and economics are being 